\title{
IDENTIFIKASI TINGKAT EMOSI MAHASISWA SEMESTER GENAP JURUSAN AKUNTANSI DAN PENGARUHNYA TERHADAP PROBLEM SOLVING TES SEDERHANA SISTEM PERSAMAAN LINEAR DUA VARIABEL (SPLDV) DAN PENINGKATANEKONOMI MAHASISWA DI STIE WIDYA GAMA LUMAJANG TAHUN ACADEMIC 2017/2018
}

\author{
Mohammad Noor Khairullah \\ Program Studi Manajemen STIE Widya Gama Lumajang \\ mohnoorkhairullah@gmail.com
}

Abstrak

Emotional Quotient (EQ) adalah kemampuan memahami perasaan diri sendiri dan orang lain, kemampuan memotivasi diri sendiri dan orang lain, kemampuan mengelola emosi dengan baik pada diri sendiri maupun pada orang lain. Dalam proses pembelajaran, siswa yang menguasai emosinya menjadi lebih percaya diri, optimis, memiliki semangat dan cita-cita, memiliki kemampuan beradaptasi, serta mereka mampu memahami, menguasai, dan memecahkan permasalahan-permalahan yang ada. Kemampuan memecahkan masalah atau problem solving tidak lepas dari pembelajaran Matematika khususnya dalam bentuk soal cerita. Oleh karena itu, tujuan penelitian ini yaitu untuk mengetahui Identifikasi Tingkat Emosi Mahasiswa Semester Genap Jurusan Akuntansi dan Pengaruhnya Terhadap Problem Solving Tes Sederhana Sistem Persamaan Linear Dua Variabel (SPLDV) Di STIE Widya Gama Lumajang Tahun Academic 2017/2018 ada atau tidak ada.

Desain penelitian ini adalah penelitian kuantitatif non-eksperimen dengan jenis penelitian korelasional. Populasi dari penelitian ini adalah semua mahasiswa semester genap jurusan Akuntansi STIE Widya Gama Lumajang Tahun Academic 2017/2018, yang terdiri dari 5 kelas. Sampel dari penelitian ini ada 3 kelas dari 5 kelas yang ada yang terdiri dari 62 mahasiswa. Peneliti menggunakan 2 instrumen yaitu angket dan tes. Analisis data menggunakan rumus Pearson Product Moment.

Dari hasil penelitian ini adalah ada pengaruh positif yang signifikan antara identifikasi tingkat emosi mahasiswa semester genap jurusan akuntansi terhadap kemampuan problem solving pada materi Sistem Persamaan Linear Dua Variabel (SPLDV) di STIE Widya Gama Lumajang Tahun Academic 2017/2018, dengan koefisien korelasi ( $r_{\text {hitung }}$ ) sebesar 0,674 lebih besar daripada $r_{\text {tabel, }}$ yaitu 0,349. Signifikasi hubungan dengan uji $t$

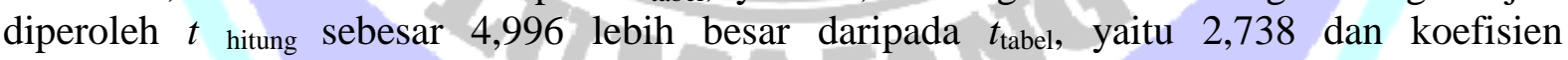
determinasinya sebesar 0,45 . Sehingga dapat disimpulkan bahwa pengaruh tingkat emosi mahasiswa semester genap jurusan akuntansi terhadap kemampuan problem solving pada materi Sistem Persamaan Linear Dua Variabel (SPLDV) di STIE Widya Gama Lumajang Tahun Academic 2017/2018 sebesar 45\%. Beberapa saran yang dapat peneliti sampaikan, yaitu: 1) Pendidik seharusnya tahu masalah dan kesulitan mahasiswa dalam pembelajaran Matematika, serta kecerdasan emosi dari masing-masing mahasiswanya. 2) Orang tua seharusnya memberikan petunjuk dan meningkatkan motivasi anak mereka untuk belajar dan mencoba untuk memecahkan masalah metematika yang berkaitan dengan kehidupan seharihari.

Kata kunci: Emotional Quotient (EQ), Kemampuan Problem Solving

PENDAHULUAN 
Problem solving merupakan hal yang penting dalam pembelajaran matematika. Hal ini karena problem solving membangkitkan minat mahasiswa untuk merespon pertanyaanpertanyaan yang diajukan. Sehingga para mahasiswa menjadi terampil memilih dan mengidentifikasi kondisi dan konsep yang relevan, mencari generalisasi, merumuskan rencana penyelesaian dan mengorganisasikan keterampilan yang telah dimiliki sebelumnya (Hudojo, 1977: 37). Bertahun-tahun telah diupayakan agar matematika dapat dikuasai mahasiswa dengan baik oleh ahli pendidikan namun hasilnya menunjukkan tidak banyak mahasiswa yang menyukai matematika dari setiap semesternya (Turmudi, 2008: 121). Hal tersebut menjadi alasan bahwa matematika penting dikuasai mahasiswa.

Polya (1985: 6) mengelompokkan fase problem solving dalam 4 fase, yaitu memahami masalah (understanding the problem), merencanakan penyelesaian (devising a plan), melaksanakan rencana (carrying out the plan), dan melihat kembali (looking back). Anwar \& Amin (4: 2013) dengan menggunakan tahapan Polya seseorang akan terbiasa untuk mengerjakan soal-soal yang tidak hanya mengandalkan ingatan yang baik saja, tetapi juga diharapkan dapat mengaitkannya dengan situasi nyata yang pernah dialaminya. Selain itu, menurut Sukayasa (44: 2012) fase-fase pemecahan masalah menurut Polya lebih populer digunakan dalam memecahkan masalah matematika dibandingkan dengan yang lainnya. Hal ini dikarenakan 1) fase-fase dalam proses pemecahan masalah menurut Polya cukup sederhana, 2) aktivitas-aktivitas pada setiap fase yang dikemukakan cukup jelas, dan 3) fasefase pemecahan masalah menurut Polya telah lazim digunakan dalam pemecahan masalah matematika (Iryani, dkk, 815: 2016). Kelebihan problem solving yaitu dapat menanggulangi masalah yang dihadapi dalam kehidupan nyata. Hal ini menunjukkan bahwa sebagian besar kehidupan manusia berhadapan dengan berbagai masalah. Karena itu pembicaraan dalam hal ini adalah problem solving dalam ruang lingkup pembelajaran matematika.

Ketidakmampuan seseorang dalam menterjemahkan soal cerita ke dalam model matematika dapat terjadi karena beberapa faktor. Faktor-faktor tersebut yaitu faktor eksternal dan faktor internal (Slameto, 1995: 24). Faktor eksternal meliputi lingkungan keluarga, lingkungan masyarakat, dan lingkungan sekolah. Sedangkan faktor internal meliputi aspek kognitif, aspek afektif, dan aspek psikomotor. Aspek afektif didominasi oleh kondisi psikologis beserta segenap potensi siswa dalam bentuk kecerdasan, termasuk kecerdasan emosional (Emotional Quotient) yang meliputi ketabahan, keterampilan bergaul, empati, kesabaran, kesungguhan, keuletan, ketangguhan, dsb (Yusuf, 2006: 44). Emotional Quotient (EQ) bertumpu pada hubungan antara perasaan, watak, dan naluri moral yang mencakup pengendalian diri, semangat dan ketekunan, kemampuan menyesuaikan diri, kemampuan penyelesaian masalah pribadi, pengendalian diri serta kemampuan untuk memotivasi diri sendiri, terutama dalam proses pembelajaran (Daud, 2012: 246).

Dalam proses pembelajaran terjadi suatu perubahan kemampuan dalam berbagai bidang, dan kemampuan itu diperoleh karena adanya usaha belajar. Seseorang yang mengendalikan emosinya menjadi lebih percaya diri, optimis, memiliki semangat dan citacita, memiliki kemampuan beradaptasi sekaligus mereka akan lebih baik prestasinya di sekolah yang mampu memahami, sekaligus menguasai permasalahan yang ada. Intelligent Quotient (IQ) menyumbang 20\% terhadap kemungkinan kesuksesan hidup, sementara $80 \%$ lainnya diisi oleh faktor lain, salah satunya yaitu Emotional Quotient (EQ) (Goleman, 2007: 44).Sehingga kecerdasan emosional (Emotional Quotient) penting dimiliki oleh setiap orang.

Ketidakmampuan seseorang dalam menterjemahkan soal cerita ke dalam model matematika dapat terjadi karena beberapa faktor. Faktor-faktor tersebut yaitu faktor eksternal dan faktor internal (Slameto, 1995: 24). Faktor eksternal meliputi lingkungan keluarga, lingkungan masyarakat, dan lingkungan sekolah. Sedangkan faktor internal meliputi aspek kognitif, aspek afektif, dan aspek psikomotor. Aspek afektif didominasi oleh kondisi 
psikologis beserta segenap potensi siswa dalam bentuk kecerdasan, termasuk kecerdasan emosional (Emotional Quotient) yang meliputi ketabahan, keterampilan bergaul, empati, kesabaran, kesungguhan, keuletan, ketangguhan, dsb (Yusuf, 2006: 44). Emotional Quotient (EQ) bertumpu pada hubungan antara perasaan, watak, dan naluri moral yang mencakup pengendalian diri, semangat dan ketekunan, kemampuan menyesuaikan diri, kemampuan penyelesaian masalah pribadi, pengendalian diri serta kemampuan untuk memotivasi diri sendiri, terutama dalam proses pembelajaran (Daud, 2012: 246).

Emotional Quotient (EQ) adalah kemampuan memahami perasaan diri sendiri, kemampuan memahami perasaan orang lain, kemampuan memotivasi diri sendiri, dan kemampuan mengelola emosi dengan baik pada diri sendiri, dan dalam hubungan dengan orang lain (Rahmawati, 2008: 22). Ada 5 karakteristik Emotional Quotient (EQ) yaitu kesadaran diri, pengaturan diri, motivasi, empati, dan keterampilan sosial (Goleman, 2007: 420). Kesadaran diri yaitu kesadaran tentang kekuatan-kekuatan dan kelemahankelemahannya, belajar dari pengalaman, perspektif yang luas, terus belajar dan mengembangkan diri sendiri. Pengaturan diri yaitu kemampuan seseorang untuk mengendalikan diri, dapat dipercaya, selalu waspada, adaptasi dan inovatif. Motivasi yaitu kemampuan seseorang memiliki dorongan berprestasi, komitmen, inisiatif, dan selalu optimis. Empati yaitu kemampuan seseorang untuk ikut merasakan apa yang dirasakan orang lain, pelayanan, membantu pengembangan orang lain, memanfaatkan keragaman serta kesadaran politik. Sedangkan keterampilan sosial yaitu Pengaruh, kemampuan seseorang terampil berkomunikasi, kepemimpinan, manajemen konflik, keakraban serta kerjasama dalam tim, katalisator perubahan.

Berdasarkan paparan di atas, peneliti ingin mengetahui pengaruh EQ terhadap kemampuan problem solving, khususnya pada materi SPLDV. Dengan demikian, peneliti akan melakukan penelitian dengan judul Identifikasi Tingkat Emosi Mahasiswa Semester Genap Jurusan Akuntansi dan Pengaruhnya Terhadap Problem Solving Tes Sederhana Sistem Persamaan Linear Dua Variabel (SPLDV) Di STIE Widya Gama Lumajang Tahun Academic 2017/2018.

\section{KAJIAN PUSTAKA}

Menurut Kamus Besar Oxford (dalam Goleman, 2007: 411) emosi adalah setiap aktivitas atau kegiatan pergolakan pemikiran, perasaan, dan keinginan, serta setiap kondisi yang sedang meningkat. Di asumsi yang lain, menurut Goleman (2007: 411) emosi adalah sebuah karakteristik dari perasaan dan pemikiran, sebuah kondisi psikologi maupun biologis yang mempunyai kecenderungan untuk bertindak sesuatu. Beberapa contoh dari emosi adalah marah, kesedihan, ketakutan, kebahagiaan, cinta, kasih sayang dan juga rasa heran. Semua emosi, pada dasarnya adalah dorongan untuk bertindak, rencana seketika untuk mengatasi permasalahan yang telah ditanamkan secara berangsur-angsur (evolusi), dan juga sebagai perasaan dan pikiran-pikiran yang khas, suatu keadaan biologis dan psikologis serta serangkaian kecenderungan untuk bertindak (Istiani, 2013: 4).

Adapun Goleman (2003: 512) mengemukakan bahwa kecerdasan emosi adalah kemampuan untuk memotivasi diri sendiri dan bertahan dalam menghadapi frustasi, mengendalikan dorongan hati dan tidak berlebih-lebihan dalam kesenangan, mengatur suasana hati dan menjaga agar bebas dari stres, tidak melumpuhkan kemampuan berpikir, berempati, dan berdoa. Dengan demikian yang dimaksud dengan kecerdasan emosional adalah kemampuan seseorang untuk memahami serta mengatur suasana hati agar tidak merusak kejernihan dalam berpikir berpikir otak rasional, tetapi mampu menampilkan beberapa kecakapan, baik kecakapan pribadi maupun kecakapan antar pribadi. 
Problem solving adalah bagian yang tidak terpisahkan dari semua pembelajaran matematika dan tidak seharusnya terisolasi dari program matematika (NCTM, 2000: 52). Ada 4 standar problem solving yang dirumuskan oleh NCTM (2000: 52), yaitu membangun pemahaman matematika baru melalui problem solving, menyelesaikan masalah yang timbul dalam matematika dan dalam konteks lain, mengaplikasikan dan mengadaptasi berbagai strategi yang tepat untuk menyelesaikan masalah, serta mengamati dan merefleksi proses dari problem solving matematika.

Menurut Robert L. Solso (Ratnasari dalam Mawaddah, 2015: 167), pemecahan masalah/problem solving adalah suatu pemikiran yang terarah secara langsung untuk menemukan solusi atau jalan keluar untuk suatu masalah yang spesifik. Sedangkan Siwono (dalam Mawaddah, 2015: 167) berpendapat bahwa problem solving adalah suatu proses atau upaya individu untuk merespon atau mengatasi halangan atau kendala ketika suatu jawaban atau metode jawaban belum tampak jelas. Problem solving telah didefinisikan sebagai proses kognitif tingkat tinggi yang memerlukan modulasi dan kontrol lebih dari keterampilanketerampilan rutin atau dasar. Jadi, problem solving adalah suatu proses atau upaya individuuntuk menemukan solusi atau jalan keluar dari suatu masalah yang memerlukan keterampilan-keterampilan rutin atau dasar.

\section{METODE}

Desain penelitian ini adalah penelitian kuantitatif non-eksperimen dengan jenis penelitian korelasional yang menggunakan analisis statistik. Pada penelitian ini, penelitian korelasional digunakan untuk mencari hubungan antara Tingkat Emosi dan kemampuan problem solving. Setelah peneliti mengenali variabel-variabel penelitian berdasarkan masalah diatas, maka variabel yang pertama adalah "timgkat emosi" yang diberi notasi huruf $(x)$, sebagai variabel bebas atau independen variabel. Sedangkan variabel yang kedua adalah "kemampuan problem solving" yang diposisikan sebagai variabel terikat atau dependen variabel yang diberi notasi huruf $(y)$.

Populasi adalah keseluruhan subjek penelitian (Arikunto, 2014: 173). Target populasi dari penelitian ini menetapkan semua mahasiswa semester genap jurusan Akuntansi STIE Widya Gama Lumajang Tahun Academic 2017/2018. Ada 172 mahasiswa, yang terbagi dalam 5 kelas. Sedangkan sampel adalah sebagian atau wakil populasi yang diteliti. Pengambilan sampel dilakukan dengan teknik random sampling yaitu cara pengambilan sampel secara acak dengan cara diundi. Peneliti mengambil sampel 3 kelas dari 5 kelas yang ada.

Hasil analisis diperoleh validasi item soal nomor 1 sebesar 0,562 dengan interpretasi sedang, nomor 2 sebesar 0,764 dengan interpretasi kuat, nomor 3 sebesar 0,763 dengan interpretasi kuat, nomor 4 sebesar 0,409 dengan interpretasi sedang, dan nomor 5 sebesar 0,540 dengan iterpretasi sedang. Berdasarkan hasil tersebut menunjukkan bahwa soal nomor 1 sampai dengan nomor 5 adalah valid. Sehingga item soal yang digunakan untuk penelitian sebanyak 5 soal.

Dalam penelitian ini, mayoritas data adalah nilai Emotional Quotient (EQ) dan nilai problem solving. Ada beberapa langkah yang dilakukan oleh peneliti dalam mengumpulkan data. Pertama, mengelola instrumen penelitian yang telah memenuhi persyaratan validitas dan reliabilitas. Kedua, instrumen penelitian diberikan kepada subjek penelitian yaitu mahasiswa semester genap jurusan Akuntansi Tahun Akademic 2017/2018 STIE Widya Gama Lumajang untuk diambil datanya. Ketiga, menghitung data yang diperoleh untuk menentukan apakah Emotional Quotient (EQ) penentu yang signifikan terhadap kemampuan problem solving 
siswa atau tidak. Dalam proses pengumpulan data, tidak ada petugas yang terlibat. Rumus yang dipergunakan adalah Pearson Product Moment.

\section{HASIL DAN PEMBAHASAN}

Hampir semua Emotional Quotient (EQ) siswa mendapat nilai cukup dalam klasifikasi EQ. Mahasiswa yang mendapat nilai baik sebanyak 30 mahasiswa (48\%), mahasiswa yang mendapat nilai cukup sebanyak 27 mahasiswa (44\%), mahasiswa yang mendapatkan nilai kurang sebanyak 4 mahasiswa (6\%), dan sangat kurang sebanyak $1(2 \%)$. Kesimpulan dari tes Emotional Quotient (EQ) yaitu tingkat EQ dari mahasiswa semester genap jurusan Akuntansi STIE Widya Gama Lumajang Tahun Academic 2017/2018 dapat mempengaruhi kemampuan problem solving mereka. Nilai kemampuan problem solving mahasiswa semester genap jurusan Akuntansi STIE Widya Gama Lumajang Tahun Academic 2017/2018 diatas rata-rata. Nilai rata-rata siswa adalah 80. siswa yang mendapat 84-100 sebanyak 36 siswa (58\%), siswa yang mendapat 68-83 sebanyak 26 siswa (42\%), dan tidak ada yang mendapatkan 36-51, 20-35 (0\%). Kesimpulan dari tes kemampuan problem solving adalah siswa harus memperbaiki kemampuan mereka dalam memecahkan masalah, karena ada faktor yang dapat mempengaruhi keberhasilan tes kemampuan problem solving yaitu salah satunya Emotional Quotient (EQ).

Koefisien korelasi antara Emotional Quotient (EQ) dengan kemampuan problem solving sebesar 0,674, hal itu berati koefisien determinasinya sebesar $r^{2}=0,45$. Dapat disimpulkan bahwa pengaruh Emotional Quotient (EQ) terhadap kemampuan problem solving sama dengan $45 \%$, sedangkan sisanya $55 \%$ ditentukan oleh faktor diluar variabel Emotional Quotient (EQ), misalnya IQ, ketelitian, dll. Hasil penelitian menunjukkan bahwa ada pengaruh kuat yang signifikan antara tingkat emosi mahasiswa semester genap Jurusan akuntansi terhadap problem solving tes sederhana Sistem Persamaan Linear Dua Variabel (SPLDV) di STIE Widya Gama Lumajang Tahun academic 2017/2018. Apabila Emotional Quotient (EQ) semakin baik maka kemampuan problem solving akan baik. Sehingga hal tersebut mengakibatkan prestasi yang didapat juga akan semakin baik.

Menurut Goleman (2007: 44) Intelligent Quotient (IQ) menyumbang tidak lebih dari $20 \%$ terhadap kemungkinan kesuksesan hidup, sementara $80 \%$ lainnya diisi oleh faktorfaktor lain. Berdasarkan hasil penelitian yang dilakukan peneliti, Emotional Quotient (EQ) berpengaruh sebesar kurang lebih $45 \%$ terhadap kemampuan problem solving dan $55 \%$ ditentukan oleh faktor lain, seperti Intelligent Quotient (IQ), motivasi belajar, self efficacy, dll. Hal ini menunjukan bahwa Emotional Quotient (EQ) lebih besar pengaruhnya daripada Intelligent Quotient (IQ) terhadap kemungkinan kesuksesan hidup seseorang. Apabila Emotional Qoutient (EQ) yang dimiliki siswa baik dan stabil, maka kemampuan problem solving siswa akan meningkat pula. Artinya, pemahaman siswa dalam menguasai materi pembelajaran Matematika semakin baik.

Dalam penelitian yang peneliti laksanakan, tentunya mempunyai banyak keterbatasan. Keterbatasan-keterbatasan tersebut adalah sebagai berikut. 1) Penelitian yang peneliti laksanakan terbatas pada satu tempat, yaitu pada mahasiswa semester genap tingkat dua STIE Widya Gama Lumajang. Sehingga kalau penelitian ini dilaksanakan pada tempat lain dimungkinkan hasilnya berbeda. Namun demikian, tempat ini dapat mewakili mahasiswa semester genap tingkat dua STIE Widya Gama Lumajang untuk dijadikan tempat penelitian dan kalau pun hasil penelitian di tempat lain berbeda tapi kemungkinan tidak akan jauh menyimpang dari hasil penelitian yang peneliti laksanakan. 2) Penelitian ini dilaksanakan selama pembuatan penelitian, waktu yang singkat inilah yang dapat mempersempit ruang gerak peneliti, sehingga dapat berpengaruh terhadap hasil penelitian yang peneliti laksanakan. Tetapi waktu yang sempit ini akan berharga sekali apabila digunakan dengan sebaik-baiknya. Oleh karena itu dalam penelitian ini, peneliti tidak melakukan uji validitas \& reabilitas 
angket, karena peneliti mengambil dokumentasi angket Emotional Quotient (EQ) dari peneliti sebelumnya. Jumlah sampel yang diteliti hanya 62 siswa dari jumlah mahasiswa semester genap tingkat dua STIE Widya Gama Lumajang, yaitu sejumlah 172 siswa. Hal ini dilakukan untuk efisiensi waktu, tenaga dan biaya. Namun demikian, karena pengambilan sampel dengan random, maka jumlah sampel ini dapat mewakili seluruh populasi. 3) Dalam penelitian ini peneliti hanya meneliti tentang Emotional Quotient (EQ) terhadap kemampuan problem solving mahasiswa, tidak Emotional Quotient (EQ) terhadap seluruh perilaku mahasiswa. Sehingga apabila Emotional Quotient (EQ) ini diterapkan dalam perilaku yang lain akan berbeda hasilnya. Hal ini dipandang kemampuan problem solving akan lebih tepat digunakan karena penelitian ini dilaksanakan dalam ruang lingkup pendidikan Matematika, sehingga kemampuan problem solving dijadikan objek dalam penelitian ini.

\section{KESIMPULAN DAN HASIL}

Hipotesis peneliti (Hi) mengatakan bahwa "Ada pengaruh kuat yang signifikan antara tingkat emosi mahasiswa semester genap Jurusan akuntansi terhadap problem solving tes sederhana Sistem Persamaan Linear Dua Variabel (SPLDV) di STIE Widya Gama Lumajang Tahun academic 2017/2018". Sedangkan hipotesis nol (Ho) mengatakan bahwa "Identifikasi tingkat emosi mahasiswa semester genap Jurusan akuntansi dan pengaruhnya terhadap problem solving tes sederhana Sistem Persamaan Linear Dua Variabel (SPLDV) di STIE Widya Gama Lumajang Tahun academic 2017/2018 tidak signifikan". Koefisien korelasi antara Emotional Quotient (EQ) dan kemampuan problem solving sebesar 0,674 lebih besar dari pada tabel nilai $r$ pada taraf $5 \%$ yaitu 0,349 . Jadi, Hi diterima dan Ho ditolak.

Kesimpulanya, ada pengaruh positif yang kuat dan signifikan antara Identifikasi tingkat emosi mahasiswa semester genap Jurusan akuntansi dan pengaruhnya terhadap problem solving tes sederhana Sistem Persamaan Linear Dua Variabel (SPLDV) di STIE Widya Gama Lumajang Tahun academic 2017/2018. Apabila Emotional Quotient (EQ) semakin baik maka akan diikuti dengan meningkatnya kemampuan problem solving mahasiswa. Emotional Quotient (EQ) terhadap kemampuan problem solving secara umum berpengaruh sebesar 45\%. Dari hasil penelitian, ditemukan hubungan antara Emotional Quotient (EQ) dengan kemampuan problem solving. Maka peneliti memberikan beberapa saran untuk guru, orang tua, mahasiswa, dan peneliti selanjutnya. 1) Pendidik seharusnya tahu masalah kesulitan mahasiswa dalam pembelajaran Matematika, serta kecerdasan emosi masing-masing mahasiswa. 2) Orang tua seharusnya tahu bakat anak mereka dan kecerdasan emosinya. 3) Mahasiswa seharusnya mengembangkan motivasi dan Emotional Quotient (EQ) mereka dalam belajar Matematika untuk meningkatkan kemampuan problem solving mereka. 4) Peneliti lain sebaiknya menambahkan variabel lain yang berkaitan dengan kemampuan problem solving dan Emotional Quotient (EQ) seperti motivasi, perilaku, kecerdasan intelektual, kecerdasan spiritual, dan lain-lain, untuk memberikan deskripsi baru bagi pembaca.

\section{DAFTAR PUSTAKA}

Abdurrahman, Mulyono. 2010. Pendidikan Bagi Anak Berkesulitan Belajar. Jakarta: Rineka Cipta.

Anwar, S. \& Amin, Siti M. 2013. Penggunaan Langkah Pemecahan Masalah Polya dalam Menyelesaikan Soal Cerita pada Materi Perbandingan Di Kelas VI MI Al-Ibrohimy Galis Bangkalan. Jurnal Pendidikan Matematika E-Pensa, 1 (1): 1-6. 
Ariefira, dkk. 2016. Proses Berpikir Siswa dalam Menyelesaikan Permasalahan pada Materi Trigonometri. Jurnal Pembelajaran Matematika. 3(1): 28-32.

Arikunto, Suharsimi. 2014. Prosedur Penelitian. Jakarta: Rineka Cipta.

Aryanti, Anis. 2016. Kumpulan Rumus-Rumus Matematika Lengkap: Sistem Persamaan Linear Dua Variabel. (online), (http://rumusrumus.com/spldv/), diakses 6 November 2016.

Ashari, Ali. 2005. The predictability of students' speaking skill from their intelligence, emotional, interest at English Department of Faculty of Teacher Training and Education (FKIP) of Islamic University of Malang (UNISMA). Thesis tidak diterbitkan. Malang: UNISMA

Baroroh, Umi. 2014. Pengaruh Model Pembelajaran Kooperatif Tipe Group Investigation Terhadap Kemampuan Pemecahan Masalah Matematika dan Kreativitas Siswa Smp Kelas VIII. Skripsi diterbitkan. Yogyakarta: Fakultas Matematika dan Ilmu Pengetahuan Alam Universitas Negeri Yogyakarta. (online), (http://eprints.uny.ac.id/12706/), diakses 19 November 2016.

BNSP. 2006. Standar Isi, Standar Kompetensi, dan Kompetensi Dasar SMP/MTs. Badan Standar Nasional, Jakarta.

Daud, Firdaus. 2012. Pengaruh Kecerdasan Emosional (EQ) dan Motivasi Belajar Terhadap Hasil Belajar Biologi Siswa SMA 3 Negeri Kota Palopo. Jurnal Pendidikan dan Pembelajaran. 19(2): 243-255.

Frederiksen, N. 1984. Implications of Cognitive Theory for Instruction in Problem Solving; Review of Educational Research; Vol. 54 (3): 363 - 407.

Gagne, R.M. \& Briggs, L.J. 1979.Principles of Instructinal Design. Second Edition; New York: Holt, Rinehart and Winston.

Goleman, Daniel. 2003. Kecerdasan Emosi untuk Mencapai Puncak Prestasi terj. Alex Tri Kantjono. Jakarta: Gramedia Pustaka Utama.

. 2007. Emotional Intelligence. Jakarta: PT Gramedia Pustaka Utama.

Greeno, J.G. 1978. Natures of Problem Solving Abilities. Dalam W.K. Estes (ed) Handbook of Learning and Cognitive Processes. Volume 5. Human Information Processing; New Jersey: Lawrence Erlbaum Associates.

Hanifah, dkk. 2016. Analisis Kesalahan Siswa Dilihat dari Skema dalam Menyelesaikan Masalah Matematika SMP Kelas VIII. Prosiding dalam Seminar Nasional, Prodi S2S3 Pendidikan Matematika Pascasarjana UM, Malang, 28 Mei.

Hidayah, Nurul. 2013. Pengaruh Penerapan Metode Problem Solving Terhadap Hasil Belajar Siswa Mata Pelajaran Matematika Pokok Bahasan Pecahan Pada Siswa Kelas IV SD Negeri Legok 1 Kabupaten Indramayu. Thesis diterbitkan. Cirebon: 
Fakultas Tarbiyah Institut Agama Islam Negeri (IAIN) Syekh Nurjati Cirebon. (online), (http://repository.syekhnurjati.ac.id/1863/), diakses 30 Juli 2017.

Hoer, Thomas R. 2007. Buku Kerja Multiple Intelligences. Bandung: KAIFA.

Hudojo, Herman. 1977. Belajar Mengajar Matematika. Jakarta: Direktorat Jenderal Pendidikan Tinggi PPLPTK.

Iryani, Siti Sa'adah, dkk. 2016. Penerapan Tahapan Polya untuk Meningkatkan Kemampuan Pemecahan Masalah Materi Statistika pada Siswa Kelas X SMKN 4 Malang. Prosidingdalam Seminar Nasional, Prodi S2-S3 PendidikanMatematikaPascasarjana UM, Malang, 28 Mei.

Istiani, Raudatun. 2013. Konsep Kecerdasan Emosi Daniel Goleman Dan Relevansinya Terhadap Kesehatan Mental Manusia. Al-Takziah. 2(1): 13-32, (online), (http://ejurnal.iainmataram.ac.id/), diakses 6 November 2016.

KEMDIKBUD. 2016. Programme For International Student Assesment (PISA). Kementerian Pendidikan dan Kebudayaan. Jakarta. (online), (http://litbang.kemdikbud.go.id/index.php/survey-internasional-pisa) $\quad$ diakses 6 November 2016.

Kurniawati, Annisa Dwi. 2014 . Pengaruh Kecemasan Dan Self Efficacy Siswa Terhadap Kemampuan Pemecahan Masalah Materi Segiempat Siswa Kelas VII MTs Negeri Ponorogo. MATHEdunesa. Vol.3. No.2. pp:36-38. (online), (http//ejournal.unesa.ac.id/index.php/mathedunesaarticle/view/8655), diakses 10 Mei 2016.

Kusumawati, Ririen. 2009. Aljabar Linear dan Matriks. Malang: UIN-Malang Press.

Lampert.M, 1990. When the Problem Is Not the Question and the Solution Is Not Answer: Mathematical Knowing and Teaching. American Educational Research Journal; Spring. Vol. 27 (1), pp $29-63$.

Latifa, dkk. 2016. Proses Pemecahan Masalah Probabilitas Siswa SMA Berdasarkan Tahapan Polya dalam Diskusi Kelompok. Prosiding dalam Seminar Nasional, Prodi S2-S3 Pendidikan Matematika Pascasarjana UM, Malang, 28 Mei.

Mawaddah, Siti, dan Hana Anisah. 2015. Kemampuan Pemecahan Masalah Matematis Siswa pada Pembelajaran Matematika dengan Menggunakan Model Pembelajaran Generatif (Generative Learning) Di SMP. Jurnal Pendidikan Matematika. 3(2): 166-175.

Max A, Sobel \& Evan M. Malestsky. 2004. Mengajar Matematika. Jakarta: Erlangga.

Musser, Garry L, dkk. 2008. Mathematics for Elementary Teacher: Contemporary Approach $10^{\text {th }}$ ed. Jefferson: RRD.

NCES. 2012. Mathematics Literacy: Average Scores. National Center for Education Statistics.

USA. (online), 
(https://nces.ed.gov/surveys/pisa/pisa2012highlights_3a.asp), diakses 6 November 2016.

NCTM. 2000. Principles and Standards for School Mathematics. The National Council of Teachers of Mathematics. USA.

Nggermanto, Agus. 2002. Quantum Quotient Kecerdasan Quantum. Bandung: Nuansa.

Novita, Rita. 2015. Korelasi Kemampuan Pemecahan Masalah Matematis Terhadap Prestasi Belajar Siswa SMP Negeri 4 Banda Aceh. Jurnal Pendidikan Matematika. Vol.2. No.1. pp:86-96. (online), (http://ejournal.stkipbbm.ac.id/index.php/mtk/article/view/219), diakses 30 Juli 2017.

Polya, G. 1985. How To Solve It $2^{\text {nd }}$ ed: A New Aspect of Mathematical Method. New Jersey: Princeton University Press.

Qin, Z., Johnson, D.W. \& Johnson R.T. 1995. Cooperative Versus Competitive Effort and Problem Solving; Review of Educational Research, Vol. 60 (2): 129 -143.

Rahadyani, Win Eka. 2003. Pengaruh Emotional Quotient (EQ) dan Lama Waktu Belajar Terhadap Prestasi Belajar Mahasiswa Jurusan Matematika FKIP UNISMA angkatan 2000/2001. Skripsi tidak diterbitkan. English Department. Teacher Training and Education Faculty. Universitas Islam Malang.

Rahmawati, Saidah. 2008. Pengaruh Intelektual Quotient (IQ), Emotional Quotient (EQ), dan Spiritual Quotient (SQ) Terhadap Prestasi Belajar Matematika Siswa Kelas X MAN Gondanglegi Kab.Malang Tahun Pelajaran 2007/2008. Skripsi tidak diterbitkan, English Department, Faculty of Teacher Training and Education, UNISMA.

Santia, Ika. 2016. Analisis Proses Berpikir Kritis Siswa SMP dalam Memecahkan Masalah Aljabar Ditinjau dari Gaya Belajar. Prosiding dalam Seminar Nasional, Prodi S2-S3 Pendidikan Matematika Pascasarjana UM, Malang, 28 Mei.

Shapiro, Lawrence E., Mengajarkan Emotional Intelligence pada Anak, Jakarta : Gramedia, 1999.

Slameto. 1995. Belajar dan Faktor-faktor yang Mempengaruhinya. Edisi Revisi, Rineka Cipta, Jakarta.

Steinberg, R.J. 1999. Cognitive Psychology. Second Edition. Philadephia: Harcout Brace Collge Publishers.

Sugiyono. 2015(a). Metode Penelitian Pendidikan (Pendekatan Kuantitatf, Kualitatif, dan $R \& D)$. Bandung: Alfabeta. . 2015(b). Statistika untuk Penelitian. Bandung: Alfabeta. 
Sukayasa. 2012. Pengembangan Model Pembelajaran Berbasis Fase-Fase Polya untuk Meningkatkan Kompetensi Penalaran Siswa SMP dalam Memecahkan Masalah Matematika. Jurnal Pendidikan Matematika AKSIOMA, 1 (1): 45-54.

Sulasmono, Bambang Suteng. 2015. Problem Solving: Signifikansi, Pengertian dan Ragamnya. Jurnal Pendidikan Matematika. Vol.3. No.1. pp: 1-13. (online), (http://ejournal.uksw.edu/satyawidya/article/view/132), diakses 30 Agustus 2017.

Turmudi. 2008. Landasan Filsafat dan Teori Pembelajaran Matematika: Paradigma Eksploratif dan Investigatif. Bandung: Leuser Cipta Pustaka.

Widowati, Dwi. 2014. Pengembangan Bahan Ajar Materi Sistem Persamaan Linear Dua Variabel Berbentuk LKS dengan Pendekatan PMRI untuk Siswa Kelas VIII Semester I. Skripsi diterbitkan. Yogyakarta: Fakultas Matematika dan Ilmu Pengetahuan Alam Universitas Negeri Yogyakarta. (online), (http://eprints.uny.ac.id/12706/), diakses 19 November 2016.

Wijaya, Aris Arya., \& Masriyah. 2013. Analisis Kesalahan Siswa dalam Menyelesaiakn Soal Cerita Materi Sistem Persamaan Linear Dua Variabel. Jurnal Pendidikan dan Pembelajaran. 3(1): 25-28. (online), (http://scholar.google.co.id/scholar url?url=http:journal.um.ac.id/index.php/pendidika n-dan-pembelajaran/article/viewFile/3475/626\&hl=id\&sa=X\&scising=AAG), diakses 5 November 2016.

Windari, F., dkk. 2014 Meningkatkan Kemampuan Pemecahan Masalah Matematika Siswa Kelas VIII SmpN 8 Padang Tahun Pelajaran 2013/2014 Dengan Menggunakan Strategi Pembelajaran Inkuiri. Jurnal Pendidikan Matematika. Vol.3 No.2. Pp: 25-28. (online), (http://ejournal.unp.ac.id/students/index.php/pmat/article/view/1182), diakses 15 Mei 2016.

Yurika, Hepry, dkk. 2015. Soal Menyelesaikan Model SPLDV dalam Kurikulum 2013 Kaitannya dengan Literasi Matematika. Prosiding dalam Seminar Nasional, Fakultas Keguruan dan Ilmu Pendidikan UPY, Yogyakarta, 10 Februari.

Yusuf, Syamsu. 2006. Psikologi Pendidikan Anak dan Remaja. Bandung: PT. Remaja Rosdakarya. 